\title{
Use of Cover Crops in Organic Sweetpotato Production to Improve Yield: A Case Report
}

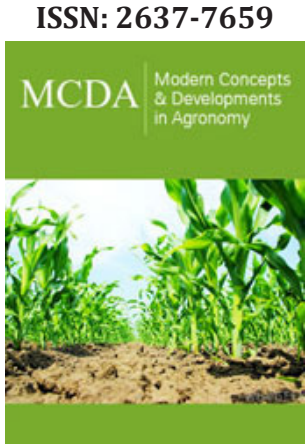

*Corresponding author: Xi Xiong, Associate Professor, Division of Plant Sciences, Columbia, Missouri, USA

Submission: 侮July 15, 2019

Published: 拝July 22, 2019

Volume 4 - Issue 5

How to cite this article: Waana Kaluwasha, Robert J Kremer, Jeanne D Mihail, Mengshi Lin, Xi Xiong. Use of Cover Crops in Organic Sweetpotato Production to Improve Yield: A Case Report. Mod Concep Dev Agrono.4(5). MCDA.000600.2019.

DOI: 10.31031/MCDA.2019.04.000600

Copyright@Xi Xiong, This article is distributed under the terms of the Creative Commons Attribution 4.0 International License, which permits unrestricted use and redistribution provided that the original author and source are credited.

\author{
Waana Kaluwasha ${ }^{1}$, Robert J Kremer ${ }^{2}$, Jeanne D Mihail ${ }^{2}$, Mengshi Lin ${ }^{3}$ and Xi \\ Xiong2* \\ ${ }^{1}$ Department of Plant Pathology and Crop Physiology, USA \\ ${ }^{2}$ Division of Plant Sciences and School of Natural Resources, USA \\ ${ }^{3}$ Division of Food System \& Bioengineering, USA
}

\begin{abstract}
Organic Sweetpotato (Ipomoea batatas (L.) Lam) production in the United States has become more popular due to consumers' concern regarding food safety. Growers, however, are challenged by many issues in organic production, including weed control that was often cited as the number one factor contributing to yield reduction. This report described a case study conducted on an organic farm in central Missouri, USA where cereal rye (Secale cereale L.) or rapeseed (Brassica napus I.) were planted as cover crops. The two crops were terminated by either tilling a couple of times or mowing followed by crimping prior to Sweetpotato transplanting. This case study demonstrated that tilling the cover crops rather than mowing and crimping resulted in significant weed control especially in the early part of the growing season. This suppression also resulted in up to three times the root tuber production, compared to the untreated control where no cover crops were planted. Between the two crops, cereal rye appeared to produce a higher yield in terms of tuber counts. This case report suggests that tilling cover crops prior to Sweetpotato transplanting can benefit organic Sweetpotato production.
\end{abstract}

Keywords: Cereal rye; Green manure; Organic farming; Rapeseed; Tillage; Weed control

\section{Introduction}

Organic farming is becoming popular, with the demand for organically produced food increasing due to an increase in consumers' concern about how their food is produced [1,2]. Due to the high costs associated with organic farming, it is estimated that organic produce often commands a $12-60 \%$ increase in market price [3], thereby attracting more farmers to organic production [2]. The increased demand for organic produce presents many opportunities for organic Sweetpotato (Ipomoea batatas (L.) Lam) growers. The growers however, cannot meet the demand due to various challenges faced in production. Weeds are often cited as the biggest hindrance to successful organic farming [4]. The nature of the Sweetpotato plant, growing close to the soil surface with spreading vines, leaves growers with only hand weeding as an option [5]. Without hand weeding, yield losses of up to $80 \%$ could occur due to weed competition [6]. There has been increased interest in cover crops recently due to their contribution to soil fertility and crop performance. Cover crops are normally grown during the off-season and could be used directly by leaving their residue on the soil surface after termination. Residues may also be incorporated into the soil after termination, in which case such cover crops are referred to as 'green manure' crops. Cover crops have been reported to reduce soil erosion [7,8], increase soil organic matter [9], improve soil physical and chemical characteristics [10], increase microbial activity [11], suppress weed populations [12] (Shilling et al., 1986), and reduce soilborne plant diseases $[13,14]$. Cereal rye (Secale cereale L.) is a widely used winter annual cover crop, due to its rapid germination, establishment and deep rooting [15]. According to Haruna et al. [16] and Teasdale et al. [17], the residues of cereal rye influence emerging crops, weeds and pests by affecting the radiation, thermal, and the hydrological environment.

Additionally, it has been shown that cereal rye residue releases phytotoxic compounds responsible for its allelopathic effects [18]; namely 2,4-dihydroxy-(2H)-1,4-benzoxazin-3(4H)one (DIBOA) and its breakdown product, benzoxazolin-2(3H)-one (BOA) [19]. Rapeseed (Brassica napus I.) on the other hand, as a Brassica species, contains glucosinolates, which are not phytotoxic in themselves, but as the plant tissues break down in soil, glucosinolates are 
converted to isothiocyanates, thiocyanates, nitriles, epithionitriles, and oxazolidine-2-thiones [20]. The glucosinolates are responsible for the herbicidal, fungicidal, and nematicidal activity of Brassica spp. [19]. As both cereal rye and rapeseed can inhibit crop plant growth due to their allelopathic activities, proper termination methods and timing for the cover crops will be essential in utilizing those crops. This case study therefore aimed to evaluate the role that cereal rye and rapeseed might play in organic Sweetpotato production and the best method for termination.

\section{Case Presentation}

This case study was carried out at Share Life Farms, a certified organic farm located in Marshall, Missouri, USA. The soil was a Sibley silt loam (fine, silty, superactive, mesic, Typic Argiudolls), with a $\mathrm{pH}$ of 6.3 and organic matter content of $2.6 \%$ and was located on a site with 1-2\% slope. In the plot area, two cover crops, either rapeseed (Brassica napus I.) or cereal rye (Secale cereale L.), were established from seeds on the $3^{\text {rd }}$ of October 2016 at rates of $7.5 \mathrm{~kg}$ or $113.0 \mathrm{~kg}$ per hectare, respectively, using a mechanical hand planter. The cover crops were terminated by two methods. One method was to keep the cover crop biomass on the soil surface by first mowing on $24^{\text {th }}$ April and then crimping using a roller crimper on $6^{\text {th }}$ June, 2017 (crimped). The second method was to till the cover crops into the soil as green manure by using a rotary tiller twice on the same dates described above (tilled). The control plots were tilled as well at the same dates as without cover crops, weeds completely occupied the plots area. After termination of the cover crops, Sweetpotato 'Beauregard' slips were transplanted into the field plots on $22^{\text {nd }}$ of June, 2017 using a planter. Within each plot, a total of 20 Sweetpotato slips in two rows were planted with an intra- and inter-row spaces of $30 \mathrm{~cm}$ and $150 \mathrm{~cm}$, respectively. Sweet potatoes were harvested between $6^{\text {th }}$ and $13^{\text {th }}$ November 2017, using a potato digger. During this growing season, no additional weed control measures were implemented, and water was provided by seasonal rainfall with no supplemental irrigation. After transplanting the Sweetpotato slips, percent weed cover in the plots area was monitored monthly from July to October. This was performed by randomly placing a $61 \mathrm{~cm} \times 61 \mathrm{~cm}$ frame three times in each plot and averaging the estimated percent weed cover within the frame. During this experiment, Sweetpotato plant vigor was estimated monthly as well, based on a 1-5 scale. In this scale, 5 indicated the best plant vigor, 1 represented a total plant death, and 3 was considered average vigor. One week after harvesting, the numbers of Sweetpotato tubers from each plant were counted and graded, based on the US Department of Agriculture market grade standards [20]. Marketable Sweetpotato tubers (at least $3.81 \mathrm{~cm}$ in diameter and free of defeats) and culls (roots that exhibited wounds and other defeats) (Figure 1) were separated and counted, and their weights were recorded. The cover crops, rapeseed or cereal rye, and their termination methods by tilling or crimping, were arranged as a $2 \times 2$ factorial combination, in addition to an untreated control where no cover crops were planted prior to Sweetpotato transplanting. The total of five treatments were organized in a randomized complete block design with 3 replications. Individual plots measured $3 \mathrm{~m} \times 6 \mathrm{~m}$ with a $7.6 \mathrm{~m}$ wide alleyway between blocks. All data collected were subjected to analysis of variance using SAS (V 9.4, SAS Institute, Inc, Cary, NC), and significant means were separated by Fisher's Protected LSD at $\mathrm{P} \leq 0.05$.

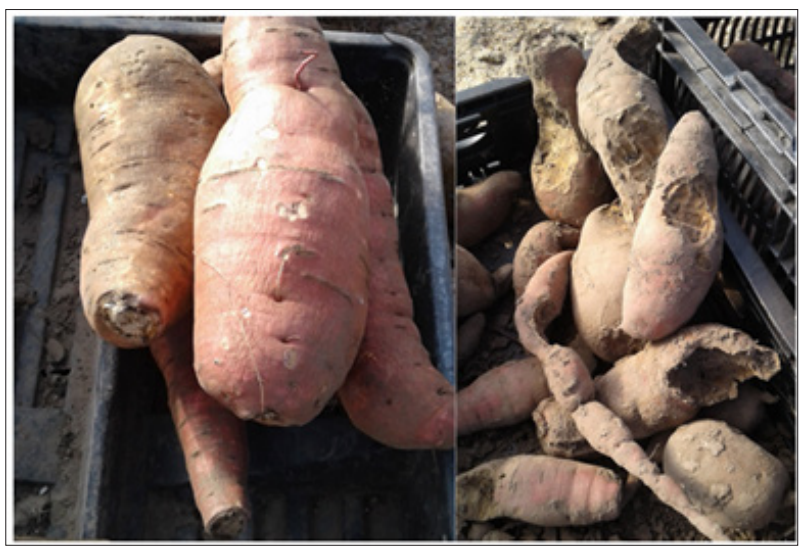

Figure 1: Representative images of marketable sweetpotato (left) or culls (right).

\section{Result and Discussion}

\section{Weeds coverage}

After transplanting the Sweetpotato slips, weed species that infested the plots area remained undisturbed intentionally. Major weed species established included grass weeds dominated by yellow foxtail (Setaria pumila (Poir.) Roem. \& Schult.), and broadleaf weeds such as Amaranthus spp., clovers (Trifolium spp.), dandelions (Taraxacum spp.), morning glory (Ipomoea purpurea (L.) Roth), henbit (Lamium amplexicaule L.), common purslane (Portulaca oleracea L.), and milkweed (Asclepias syriaca L.). Occurrence of the weeds in the plots area was significantly influenced by the interaction between the treatment applied and evaluation date (Table 1). In July about three weeks after Sweetpotato transplanting, plots with crimped cover crops, regardless of species, resulted in $13 \%$ or greater weed density. In contrast, plots that were tilled, including the control plots, resulted in $4 \%$ or less weed density. In August, weeds had spread out substantially, and reached $100 \%$ in the control plots where the Sweetpotato plants were barely visible, indicating a serious shade issue. Plots planted with cover crops prior to Sweetpotato planting demonstrated significantly less weed infestation, ranging from $53 \%$ to $73 \%$ in coverage. Regardless of 
species, cover crops that were tilled into the soil resulted in up to a $27 \%$ reduction in weed density, compared to plots with crimped cover crops. This result suggested a superior weed suppression by tillage incorporation of the cover crops. In September or October, all plots showed $90 \%$ or greater weed density, regardless of treatment. Collectively, these results demonstrated that cover crops can inhibit weed establishment [21]; however, this effect was confined only to the early part of the growing season. Compared to plots where cover crops were crimped, termination of the cereal rye and rapeseed plants by tilling likely released the allelopathic compounds into the soil prior to Sweetpotato transplanting, which resulted in a better inhibition of weed species in the first two months [15,22].

Table 1: Percent weed cover (\%) influenced by the interaction of treatment applied and the evaluation timing. Treatments applied included the combination of cover crop species, cereal rye or rapeseed, and the termination methods, tilled or crimped, in addition to an untreated control where no cover crops were planted, and the plots were tilled prior to sweetpotato transplanting.

\begin{tabular}{|c|c|c|c|c|c|}
\hline \multirow{2}{*}{ Evaluation Date } & \multicolumn{2}{|c|}{ Tilled } & \multicolumn{2}{|c|}{ Crimped } & \multirow{2}{*}{$\begin{array}{c}\text { Tilled } \\
\text { Control }\end{array}$} \\
\hline & Cereal Rye & Rapeseed & Cereal Rye & Rapeseed & \\
\hline July & $1 \mathrm{cC}^{\mathrm{z}}$ & $4 \mathrm{bcC}$ & $13 \mathrm{abc}$ & $17 \mathrm{aC}$ & $2 \mathrm{cB}$ \\
\hline August & $57 \mathrm{cB}$ & $53 \mathrm{cB}$ & $73 \mathrm{bB}$ & $73 \mathrm{bB}$ & $100 \mathrm{aA}$ \\
\hline September & $90 \mathrm{aA}$ & $90 \mathrm{aA}$ & $95 \mathrm{aA}$ & $95 \mathrm{aA}$ & $100 \mathrm{aA}$ \\
\hline October & $90 \mathrm{aA}$ & $90 \mathrm{aA}$ & $95 \mathrm{aA}$ & $95 \mathrm{aA}$ & $100 \mathrm{aA}$ \\
\hline
\end{tabular}

${ }^{z}$ Means followed by the same lowercase letter within the same row were not significantly different based on the Fisher's Protected LSD (P $\leq 0.05)$; Means followed by the same capital letter within the same column were not significantly different based on Fisher's Protected LSD ( $\mathrm{P} \leq 0.05)$.

\section{Sweetpotato plant vigor and yield}

After transplanting, the growth of the Sweetpotato plants was significantly influenced by treatments applied (Figure 2). Regardless of cover crop species, Sweetpotato plants growing in plots where cover crops were crimped showed an average or low vigor during the entire growing season. In contrast, plants that were in plots where the cover crops were tilled demonstrated the highest plant vigor at all evaluation timings. Similarly, Sweetpotato plants growing in the control plots, despite the full coverage of weeds during most of the growing season (Table 1), displayed little to no reduction in plant vigor. These results suggested that shade from weeds did not seriously affect Sweetpotato plant growth. Instead, the method of termination of cover crops, both with allelopathic properties, played a significant role in Sweetpotato plant growth. Specifically, the first tillage that occurred two months before Sweetpotato transplanting likely released most if not all allelopathic compounds into the soil before Sweetpotato transplanting. In contrast, the cover crops likely remained partially alive after mowing in April, until the crimping that occurred three weeks prior to Sweetpotato transplanting. This likely resulted in plant residues that continued releasing the allelopathic compounds, and subsequently caused an adverse influence on the growth of Sweetpotato slips [23-25].

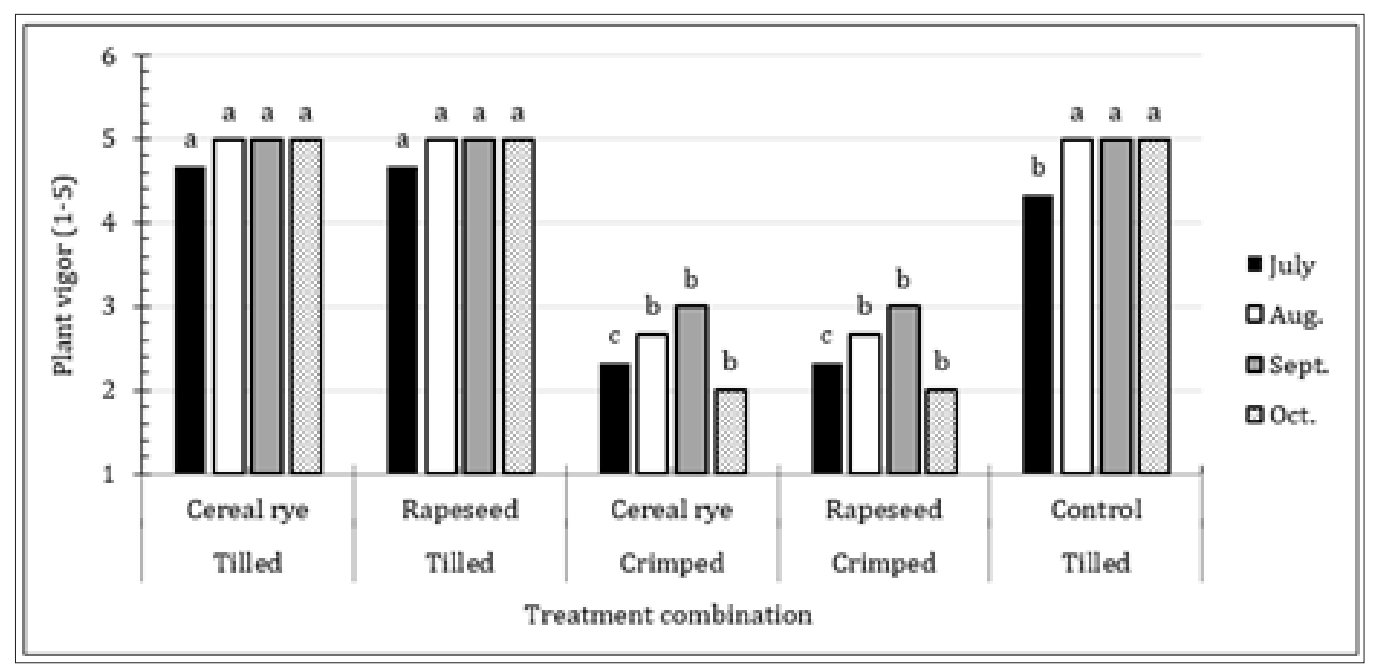

Figure 2: Sweetpotato plant vigor (1-5) influenced by treatment applied. Bars labeled with the same letters at each evaluation timing are not significantly different based on Fishers' Protected LSD at P $\leq 0.05$. 
The visual assessment of plant vigor during the production positively correlated with the Sweetpotato root tuber yield (Figure $3 \& 4$ ). None of the Sweetpotato plants in crimped cover crop plots produced any tubers (Figure 3). In contrast, all other plots including the controls produced marketable tubers. On average, each Sweetpotato plant produced approximately six total or one marketable tubers, which were 1.8 or 3 times the yield of individual plants growing in the control plots, respectively. It is also interesting that Sweetpotato plants growing in plots after tilling cereal rye resulted in 1.5 times tuber yield, compared to plants growing in plots that had rapeseed. Subsequently, on average, each individual Sweetpotato plant produced 231 or 173g of Sweetpotato tubers in plots where cereal rye or rapeseed were tilled, respectively (Figure 4). Although control plots yielded statistically comparable tuber weight, it was not different from crimped plots where no yield was detected. This result suggested a highly variable nature in the control plots where yield was inconsistent and not reliable.

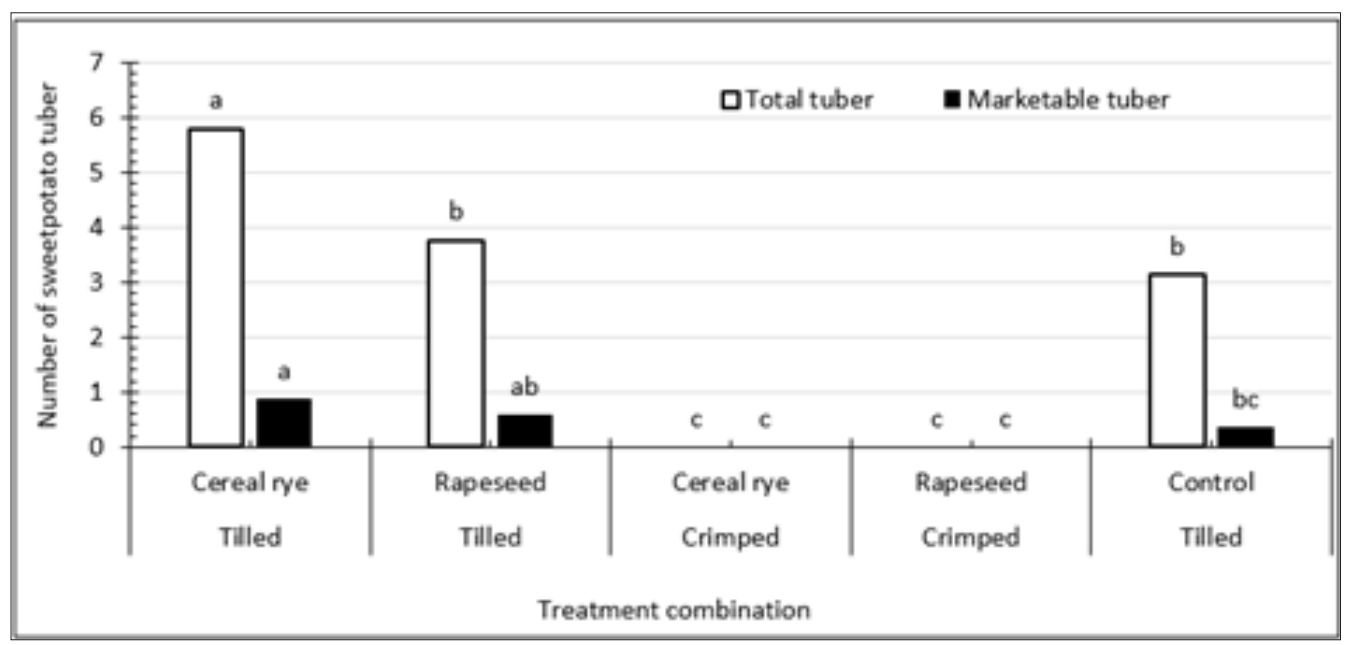

Figure 3: Sweetpotato total and marketable root tuber counts per plant influenced by treatment applied. Bars labeled with the same letters for each parameter are not significantly different based on Fishers' Protected LSD at $\mathrm{P} \leq 0.05$.

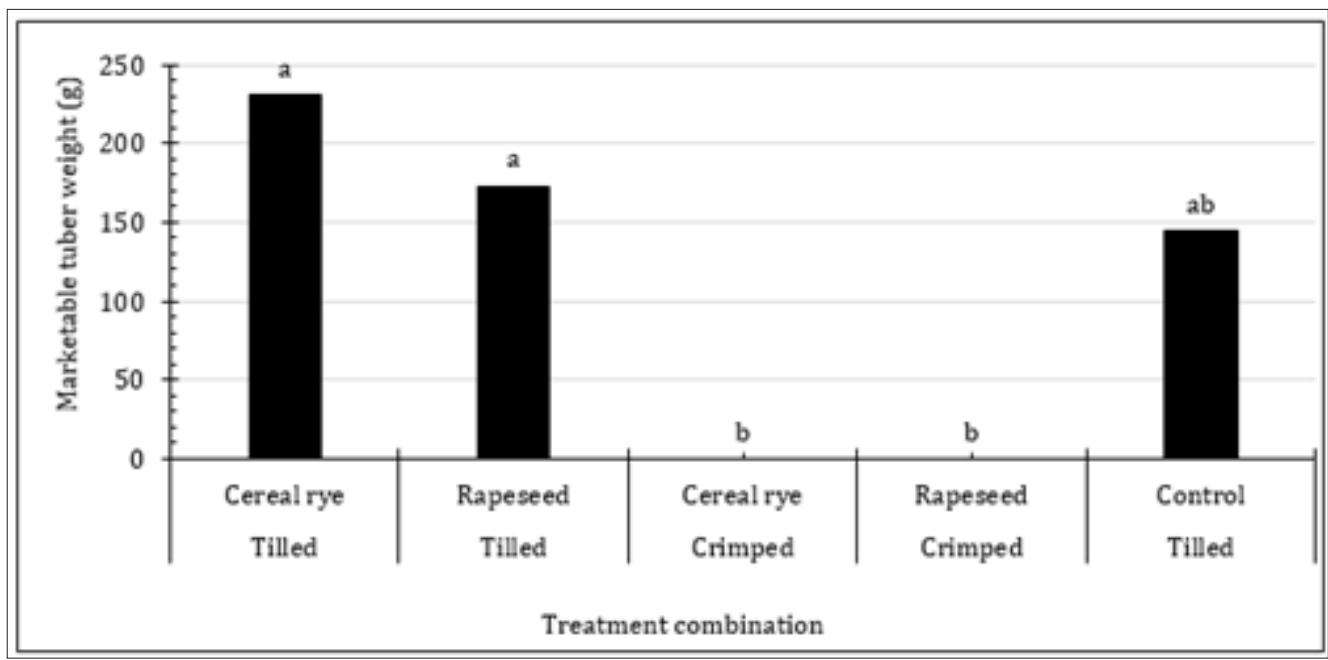

Figure 4: Sweetpotato marketable root tuber weight (g) per plant influenced by treatment applied. Bars labeled with the same letters are not significantly different based on Fishers' Protected LSD at $\mathrm{P} \leq 0.05$.

\section{Summary}

Collectively, this case study demonstrated that both cereal rye and rapeseed can be candidates for cover crops in organic Sweetpotato production where weed control practices are minimally implemented. The method of cover crop termination, however, plays an essential role in successful production. Tilling the cover crops into the soil suppressed weeds from establishment during the early growing season, and resulted in dependable and elevated root tuber yield. In contrast, crimping the cover crops three weeks prior to the Sweetpotato transplanting led to reduced Sweetpotato plant vigor and zero tuber yield. Between the two cover crops, cereal rye appeared to promote tuber production compared to rapeseed after tillage. Overall, this case report suggests that tillage incorporation of cover crops, such as cereal rye, could be integrated in organic Sweetpotato production systems as part of a weed management practice. 


\section{Acknowledgement}

The authors appreciate Mr. James Thomas, Jr., the owner of Share Life Farms, in Marshall, Missouri, USA, for providing the research site and assisting in the research. This project is partially funded by the North Central Research Sustainable Agriculture Research \& Education (NCR SARE) Graduate Student Grant Program, with award number GNC16-226.

\section{Conflict of Interest}

The authors declare that there is no conflict of interest.

\section{References}

1. Govindasamy R, Italia J (1998) A willingness-to-purchase comparison of integrated pest management and conventional produce. Agribusiness 14(5): 403-414.

2. Thompson GD (1998) Consumer demand for organic foods: What we know and what we need to know. American Journal of Agricultural Economics 80(5): 1113-1118.

3. Lohr L (1998) Implications of organic certification for market structure and trade. American Journal of Agricultural Economics 80: 1125-1129.

4. Beveridge LE, Naylor RE (1999) Options for organic weed control-what farmers do. In: Brighton Crop Protection Conference on Weeds 3: 939944.

5. Treadwell DD, Creamer NG, Schultheis JR, Hoyt GD (2007) Cover crop management affects weeds and yield in organically managed sweetpotato systems. Weed Technology 21(4): 1039-1048.

6. Jackson DM, Harrison HF (2008) Effects of a killed-cover crop mulching system on Sweetpotato production, soil pests, and insect predators in South Carolina. Journal of Economic Entomology 101(6): 1871-1880.

7. Creamer NG, Bennett MA, Stinner BR (1997) Evaluation of cover crop mixtures for use in vegetable production systems. HortScience 32(5): 866-870.

8. Wall GJ, Pringle EA, Sheard RW (1991) Intercropping red clover with silage corn for soil erosion control. Canadian Journal of Soil Science 71(2): 137-145.

9. Allison FE (1973) Soil organic matter and its role in crop production. Elsevier, New York, USA p. 639.

10. Reid JB, Goss MJ (1981) Effect of living roots of different plant species on the aggregate stability of two arable soils. European Journal of Soil Science 32(4): 521-541.
11. Cook RJ, Baker KF (1983) The nature and practice of biological control of plant pathogens. The American Phytopathological Society Press, St. Paul, Minnesota, USA, p. 539.

12. Shilling DG, Jones LA, Worsham AD, Parker CE, Wilson RF (1986) Isolation and identification of some phytotoxic compounds from aqueous extracts of rye (Secale cereale L.). Journal of Agricultural and Food Chemistry 34(4): 633-638.

13. Abawi GS, Crosier DC (1992) Influence of reduced tillage practices on root rot severity and yield of snap beans, 1991. Biological and Cultural Tests 7: 9.

14. Viaene NM, Abawi GS (1998) Management of Meloidogyne hapla on lettuce in organic soil with sudangrass as a cover crop. Plant Dis 82(8): 945-952.

15. Rice CP, Park YB, Adam F, Abdul Baki AA, Teasdale JR (2005) Hydroxamic acid content and toxicity of rye at selected growth stages. J Chem Ecol 31(8): 1887-1905.

16. Haruna SI, Anderson SH, Nkongolo NV, Reinbott T, Zaibon S (2017) Soil thermal properties influenced by perennial biofuel and cover crop management. Soil Science Society of America Journal 81(5): 1147-1156.

17. Teasdale JR, Abdul Baki AA, Mills DJ, Thorpe KW (2004) Enhanced pest management with cover crop mulches. Acta Horticulturae 638: 135-140.

18. Weston LA (1996) Utilization of allelopathy for weed management in agroecosystems. Agronomy Journal 88(6): 860-866.

19. Fenwick GR, Heaney RK, Mullin WJ, VanEtten CH (1983) Glucosinolates and their breakdown products in food and food plants. CRC Critical Reviews in Food Science and Nutrition 18(2): 123-201.

20. US Department of Agriculture (2005) U.S. standards for grades of sweet potatoes.

21. Haramoto ER, Gallandt ER (2005) Brassica cover cropping: I. Effects on weed and crop establishment. Weed Science 53(5): 695-701.

22. Boydston RA, Hang A (1995) Rapeseed (Brassica napus) green manure crop suppresses weeds in potato (Solanum tuberosum). Weed Technology 9(4): 669-675.

23. Burgos NR, Talbert RE (2000) Differential activity of allelochemicals from Secale cereale in seedling bioassays. Weed Science 48(3): 302-310.

24. Rehman MU, Hussain M, Ali M, Mustafa CB, Shafi J, et al. (2013) Allelopathy of Brassica. A review. Scientia Agriculturae 3(2): 46-53.

25. Barnes JP, Putnam AR, Burke BA, Aasen AJ (1987) Isolation and characterization of allelochemicals in rye herbage. Phytochemistry 26(5): 1385-1390. 